УДК 811.11’42:159.946.3

Скрябіна Вікторія Борисівна

кандидат філологічних наук, доцент, Київський національний лінгвістичний університет, Київ, Україна, skryabina.ya@gmail.com

\title{
ЛІНГВІСТИЧНІ АСПЕКТИ ПЕРСУАЗИВНОСТІ В ДИПЛОМАТИЧНОМУ ДИСКУРСІ
}

Метою статті є дослідження лінгвістичних аспектів персуазивності в дипломатичному дискурсі. За допомогою дискурсивного аналізу було встановлено особливості дипломатичного дискурсу, а мовні засоби персуазивності розглянуто за допомогою методів семантичного, синтаксичного та стилістичного аналізу. У результаті дослідження надано визначення персуазивності як комунікативного явища, що передбачає здійснення впливу адресанта на думку, враження, ставлення, почуття, емоції адресата та включає раціонально-логічний і афективний компоненти. Встановлено характерні ознаки дипломатичного стилю: інтердискурсивність, наявність масового адресата, використання кооперативних і конфронтативних стратегій, ритуалізованість, діалогічність, а також персуазивність. Докладно проаналізовано мовні засоби персуазивного впливу, лексичні, граматичні, синтаксичні та стилістичні. Серед персуазивних лексичних засобів варто відзначити етикетні кліше, терміни та фразеологізми, абревіатури, інтернаціональну та книжну лексику, які надають особливу тональність дипломатичному документу. Використання граматичних засобів персуазивності (найвищого ступеню порівняння прикметників i прислівників, інтенсифікаторів, інфінітивних, віддієслівних i паралельних конструкцій) допомагає акцентувати та виокремити важливі елементи в дипломатичних текстах. У свою чергу стилістичні засоби, перш за все епітети, метафори та метонімія, сприяють переконливості дипломатичних промов i звернень. Здобуті результати сприяють подальшій науковій розробці проблеми персуазивної комунікації.

Ключові слова: персуазивність, дипломатичний дискурс, лексичні засоби персуазивності, граматичні засоби персуазивності, стилістичні засоби персуазивності.

Skriabina Viktoriia, Candidate of Linguistics, Associate Professor, Kyiv National Linguistic University, Kyiv, Ukraine

Linguistic aspects of persuasion in diplomatic discourse 
The article is aimed at the study of linguistic aspects of persuasion in diplomatic discourse. The discursive analysis has been employed to establish features of diplomatic discourse, whereas the methods of semantic, syntactic and stylistic analyses have been applied to examine linguistic means of persuasion. As a result of the study, persuasion has been defined as a communicative phenomenon which has an impact on the addressee's opinions, impressions, attitude, feelings, and emotions and includes rational-logical and affective components. Characteristic features of diplomatic style, such as interdiscursiveness, the presence of a mass addressee, the use of cooperative and confrontational strategies, ritualization, dialogical nature, and persuasiveness have been established. Linguistic means of persuasion, namely lexical, grammatical, syntactic and stylistic, have been analyzed in detail. Lexical means of persuasion include etiquette clichés, terms and idioms, abbreviations, international and bookish vocabulary which add a special tonality to the diplomatic document. The use of grammatical means of persuasion (the superlative degree of adjectives and adverbs, intensifiers, infinitive, verbal and parallel constructions) helps to accentuate and highlight important elements in diplomatic texts. In turn, stylistic means, especially epithets, metaphors and metonymy, contribute to the credibility of diplomatic speeches and addresses. The obtained results contribute to further scientific development of the problem of persuasive communication.

Key words: persuasion, diplomatic discourse, lexical means of persuasion, grammatical means of persuasion, stylistic means of persuasion.

Скрябина Виктория Борисовна, кандидат филологических наук, доцент, Киевский национальный лингвистический университет, Київ, Украӥна

Лингвистические аспекты персуазивности в дипломатическом дискурсе

Целью статьи является исследование лингвистических аспектов персуазивности в дипломатическом дискурсе. С помощью дискурсивного анализа установлены особенности дипломатического дискурса, языковые средства персуазивности рассмотрены с помощью методов семантического, синтаксического и стилистического анализа. В результате исследования дано определение персуазивности как коммуникативного явления, которое предусматривает воздействие адресанта на мнение, впечатление, отношение, чувства, эмоции адресата и включает рационально-логический и аффективный компоненты. Установлены такие характерные признаки дипломатического стиля, как интердискурсивность, наличие массового адресата, использование кооперативных и конфронтативных стратегий, ритуализованость, диалогичность, а также персуазивность. Подробно проанализированы языковые средства персуазивности, лексические, грамматические, синтаксические и стилистические. Среди лексических средств персуазивности следует отметить 
этикетные клише, термины и фразеологизмы, аббревиатуры, интернациональную и книжную лексику, которые придают особую тональность дипломатическому документу. Использование грамматических средств персуазивности (высшей степени сравнения прилагательных и наречий, интенсификаторов, инфинитивных, отглагольных и параллельных конструкций) помогает акцентировать и выделить важные элементы в дипломатических текстах. В свою очередь стилистические средства, прежде всего эпитеты, метафоры и метонимия, способствуют убедительности дипломатической речи и обращений. Полученные результаты способствуют дальнейшей научной разработке проблемы персуазивной коммуникации.

Ключевые слова: персуазивность, дипломатический дискурс, лексические средства персуазивности, грамматические средства персуазивности, стилистические средства персуазивности.

Вступ. Сучасна міжнародна діяльність визначається переструктуруванням усього світового політичного простору. «Світ постміжнародної політики» (Дж. Розенау) став непередбачуваним, інформаційним та надзвичайно персуазивним. Тоді як раніше в дипломатичному спілкуванні мав зберігатися нейтралітет, а особистісний, суб'єктивний момент у ньому зводився до мінімуму, сьогоднішній дипломатичний дискурс під впливом соціальнополітичних змін стає більш агресивним та експресивним. Сучасна дипломатія включає багато нехарактерних для неї раніше сфер, таких як взаємодія 3 громадськістю, координація зусиль 3 врегулювання конфліктів. Форми дипломатичної діяльності також стають все більш різноманітними й сьогодні не обмежуються лише діяльністю посольств. У зв’язку 3 цим прагматика дипломатичного дискурсу становить неабиякий інтерес для лінгвістів. Ключовою в дипломатичній комунікації є функція персуазивного впливу.

Аналіз останніх досліджень і публікацій. Окремі аспекти дипломатичних текстів розглядали Е. Сатоу, Х. Вільднер, Дж. Вуд та Ж. Серре; стиль дипломатичних документів як складову частину офіційно-ділового стилю досліджували В. Т. Адмоні, Т. І. Сільман, В. Д. Левіна та ін. Серед українських дослідників варто відзначити праці Н. М. Поліщук та О. М. Мацько. Про експресивність дипломатичних термінів пише Н. С. Кащишин. Мовленнєвий вплив розглядають у різних видах інституційного дискурсу (А. М. Баранов, Р. Лакофф, О. М. Леонтьєв, Й. А. Стернін, В. С. Чернявська, О. І. Шейгал), проте лінгвістичний аспект персуазивності дипломатичного дискурсу ще не був об'єктом окремого дослідження.

Виділення невирішених раніше частин загальної проблеми. Формулювання цілей статті. У статті ставимо за мету з'ясувати, які мовні засоби складають основу персуазивності англомовного дипломатичного 
дискурсу. Досягнення поставленої мети передбачає уточнення поняття персуазивності в дипломатичному тексті, виокремлення характерних ознак дипломатичного стилю та встановлення лексичних, граматичних та стилістичних засобів персуазивності дипломатичного дискурсу.

Виклад основного матеріалу дослідження. Мистецтво переконання 3 давніх часів складало основу дипломатії, оскільки передбачало налагодження контакту і взаємопорозуміння у процесі переговорів. За В. С. Чернявською, персуазивність - це здійснення впливу адресанта на думку, враження, ставлення, почуття, емоції адресата [9, с. 25]. Особливого значення персуазивність, або вміння переконувати набуває у сучасній превентивній дипломатії покликаній попереджувати виникнення суперечок між сторонами, недопущення переростання існуючих суперечок у конфлікти і обмеження масштабів конфліктів після їхнього виникнення [4].

Персуазивність - це певний вплив автора усного чи письмового повідомлення на його адресата 3 метою переконання в чомусь, заклику до певних дій [2]. Персуазивність передбачає наявність дихотомії раціонального переконання і емоційно-маніпулятивного зваблювання реципієнта [11]. Згадаємо таких талановиті митців Середньовіччя як, наприклад, Данте, Петрарка, Бокаччо, які водночас були видатними дипломатами. Вміння поєднати логічне та ірраціональне складало основу їхнього таланту переконувати. Серед відомих дипломатів зустрічаємо також літераторів (Джеффрі Чосер) та філософів (Нікола Макіавеллі, Джон Локк, Жан-Жак Руссо).

Тривалий час лінгвісти не виокремлювали дипломатичний дискурс. Його розглядали в складі політичного дискурсу. Проте тепер з'являються поодинокі спроби визначити це поняття. Дипломатичний дискурс - це комплексне комунікативне явище, ... що охоплює всю палітру мовленнєвих інтеракцій (актів) дипломатів, реалізується в усній та писемній формі, регламентується жорсткими рамками як загальних (міжнародних), так і етноспецифічних правил, існуючих історичних традицій, риторико-стилістичних норм, а також має власні характерні риси [5].

Характерними ознаками дипломатичного дискурсу вважають інтердискурсивність [5], наявність масового адресата, використання кооперативних та конфронтативних стратегій [7], ритуалізованість [13, с. 41], діалогічність, а також персуазивність [8]. Інтердискурсивність у дипломатичному дискурсі проявляється в широкій тематиці термінів, адже відсоток текстів із суто дипломатичних питань не такий вже й високий. Згідно 3 О. Пономаренко, дипломатична термінологія включає елементи медичного, фізичного, архітектурного, будівельного, літературного, театрального та ін. дискурсів [5]. Наявність масового адресата пояснюють тим, що сьогодні завдяки технічному прогресу велика кількість промов та звернень під час 
офіційних засідань, а також дипломатичних документів є у відкритому доступі і будь-хто може 3 ними ознайомитися [7]. Використання кооперативних та конфронтативних стратегій визначає успіх дипломатичної комунікації. Зокрема, негативна тональність, навмисна двозначність свідчать про конфронтативну інтенцію дипломата. Натомість позитивна тональність, стриманість у висловленнях демонструють обережне ставлення до комунікативного партнера [13, с. 41].

Однозначність і точність викладу, лаконічність формулювань вимагають використання відповідних мовленнєвих кліше, спеціальної термінології і певної структури, що і пояснює високу ритуалізованість дипломатичного дискурсу.

Ідеї діалогічності спілкування, розроблені свого часу М. М. Бахтіним, стають актуальними для дипломатії. Дипломатичний діалог передбачає визнання того, що в іншої сторони є власні інтереси і цілі. Звідси важливим є не директивне нав'язування власної точки зору, а прагнення через діалог шукати взаємоприйнятне рішення проблем. Сучасні дипломатичні концепції передбачають орієнтацію на взаємне задоволення інтересів і відкритий характер переговорів, адже у багатьох випадках потрібні спільні зусилля для вирішення глобальних проблем, пов'язаних 3 екологією, боротьбою 3 тероризмом, врегулюванням конфліктів, розвитком інтеграційних процесів і т. п. У результаті, рішення міжнародних проблем об'єктивно стає головною функцією дипломатії.

Слово виступає зброєю в сучасному глобалізованому суспільстві, недарма найбільший коефіцієнт воєн проходить в інформаційному вимірі. Т. ван Дейк поділяє вплив на легітимний та нелегітимний [11, с. 359-383]. Легітимним видом впливу $є$ персуазивність, а нелегітимним - маніпулятивність. Маніпулятивність нелегітимна, оскільки, вона порушує соціальні правила та норми, а також права людей. Нелегітимні соціальні практики здійснюються лише в інтересах однієї сторони та порушують права та інтереси адресата. Маніпулятивність у гібридному дипломатичному дискурсі передбачає зловживання владою, контроль над мисленням, знаннями, позиціями, віруваннями людей. Цей контроль здійснюється за допомогою текстів, розмов та візуальних повідомлень, в яких має місце навмисне викривлення фактів (дезінформації, відбору інформації), створення ілюзій, міфів тощо [11, с. 364]. На відміну від маніпулятивності, яка передбачає неусвідомленість впливу об'єктом маніпуляції та відсутність свободи вибору у останнього, персуазивність є етичним видом впливу. Тому на ньому й зосередимо свою увагу.

Здійснення персуазивного впливу в дипломатичній комунікації передбачає використання мови як основного інструменту переконання. Вплив на адресата можна чинити шляхом привертання уваги, створення сприятливого емоційного 
фону, використання особливого комплексу лексичних, граматичних, синтаксичних і стилістичних засобів.

До лексичних засобів з персуазивним потенціалом відносимо, перш за все, кліше, терміни та фразеологізми, наприклад, on behalf of, bearing in mind, atmosphere of trust and confidence та ін.

Використання спеціальної термінології, назви посад, дипломатичних установ і закладів, документів та дипломатичних дій сприяє персуазивності дипломатичного спілкування, оскільки $є$ безпосереднім засобом впливу. За Арістотелем, етос як одна 3 категорій риторики визначає успіх оратора [1]. Промовець вибудовує власний авторитет, довіру слухачів. Принцип авторитету $є$ одним із основоположних у персуазивній взаємодії [10], адже він грунтується на схильності людей до покори відповідно до вимог авторитету. Тенденція підкорятися законним авторитетам є підсвідомою, зумовленою багатовіковою практикою навіювання членам суспільства думки про те, що така покора $\epsilon$ правильною i часто уявляється людям раціональним способом прийняття рішення. Сила використання дипломатичних термінів зростає завдяки їх впливу на підсвідомість: до них починають ставитися 3 великою повагою чи прихильністю, хоча вони не мають жодних інших реальних переваг.

До лексичних засобів персуазивності можемо віднести використання абревіатур, загальноприйнятих символів та скорочень у дипломатичному листуванні (F.S.O. - Foreign Service officer., D.C.M. - deputy chief of mission, DEL-Delegation, etc.).

Інтернаціональну лексику також вважаємо персуазивною, оскільки вона допомагає уникнути багатозначності, є чіткою і зрозумілою. Так, звучання i частково написання слова attaché в англійській, українській, німецькій i французькій мовах збігається (укр. amame, нім. Attachee, фp. attaché). Загалом це запозичення з латинської і французької мов, деякі також з грецької мови. Іноді в дипломатичних текстах латинські терміни вживають в оригінальному написанні: persona non grata, status quo, nраво veto і т. д. Наявність спільних лексем сприяє налагодженню взаєморозуміння, апелює до персуазивного принципу прихильності [10]. Відповідно до цього принципу - ми відчуваємо симпатію до людини, яка чимось схожа на нас. Це робить нас відкритими до іiі аргументів i викликає позитивні асоціації.

У дипломатичних документах часто вживається книжна та етикетна лексика, яка надає їм урочистості: honorable guests, your Excellency, Mr./Madam Ambassador i т. п. Використовують також т. зв. компліментарну лексику (протокольні офіційні формули дипломатичної ввічливості): request the pleasure of your company, свідчити повагу, прийняти запевнення в повазі (в глибокій nовазі) тощо. Багато з цих протокольних, офіційних формул мають міжнародний характер і надають особливу тональність дипломатичному документу. 
Додамо також, що лексичний потенціал мови сприяє тому, що одне й те ж послання можна передаватися й сприйматися по-різному. Дипломати завжди цим послуговувалися. Нюансування слів і понять дає безліч можливостей для умілої дипломатії. За королювання Генріха IV французький дипломат Жаннен приїхав до Голландії з посередницькою місією - схилити Сполучені провінції $\mathrm{i}$ Іспанію до переговорів про мир. Але ні принц Оранський, ні король Іспанії не бажали вести переговори, які тривали понад 2 роки. Жаннен у своєму дипломатичному посланні замінив слово «мир» виразом «тривале перемир'я». Для самолюбних монархів, які не хотіли погоджуватися на мир, перемир'я виявилося більш прийнятною альтернативою.

Персуазивному дипломатичному мовленню притаманна оцінність, тому лексеми 3 позитивною чи негативною конотацією тут також широко використовують: honour, dignity, honesty, integrity, deep, extreme, immense, tremendous, powerful, disastrous, effective, etc. Такі лексичні одиниці передають інтенсивність характеристик понять чи явищ міжнародного життя.

До граматичних засобів персуазивності зараховуємо вживання найвищого ступеню порівняння прикметників $\mathrm{i}$ прислівників (highest consideration, my best wishes, kindest regards, greatest pleasure, etc.), інтенсифікаторів (especially deep dimension, very impressed by the abilities, so happily exist, etc.), а також імперативні конструкції в текстах ультиматумів. Інфінітивні, віддієслівні та паралельні конструкції, поширені в текстах договорів і резолюцій, містять персуазивний потенціал, акцентують та виокремлюють важливе: expressing grave concern, deploring the violation of human rights, expressing deep concern, rejecting unequivocally, welcoming the condemnation; to act with the utmost restraint, to allow immediate access for international human rights monitors, to ensure the safety, etc.

Синтаксис дипломатичних документів відрізняється складністю, в ньому переважають довгі складнопідрядні та складносурядні речення, велика кількість однорідних членів, які підкреслені графічно за допомогою абзацного членування конструкції. Для синтаксису дипломатичних документів характерним $\epsilon$ вживання умовних речень, що відповідає вимогам дипломатичного етикету, дипломатичного такту.

Персуазивного впливу в дипломатичному дискурсі досягають завдяки використанню стилістичних засобів, зокрема епітетів (gross violation, drastic changes, sweeping actions, bright future), метафор (ping-pong diplomacy, gift-basket diplomacy, gunboat diplomacy, shuttle diplomacy, etc.), метонімії (relations between England and Australia, Downing Street, etc. ) тощо. Найчастіше стилістичні засоби персуазивності використовують у дипломатичних промовах, переговорах, телеграмах та тостах. 
Писемні жанри дипломатичного дискурсу більш стандартизовані, відрізняються строгою композицією тексту, точним і ретельним відбором фактів і способом їхньої подачі, нульовою емоційністю. Дотримання цих вимог уже є персуазивним кроком. Натомість, різкі критичні висловлення, риторичні звороти, натяки недопустимі в дипломатичному спілкуванні і знижують його ефективність.

Об’єктивність у дипломатичних документах реалізують завдяки граматичним категоріям (часові форми, модальні дієслова тощо). Зокрема форми простих часів виражають констатацію фактів у певному часовому відсіку, ілюструють конкретність дії, іноді підкреслюючи актуальність розв'язання певної проблеми [3, с. 96].

У цьому аспекті варто також згадати про існування в дипломатії принципу взаємності [6], коли при складанні ноти-відповіді необхідно враховувати характер комплімента. На вербальні ноти прийнято відповідати вербальними, на особисті - особистими. Не прийнято вживати комплімент у випадку оголошення жалоби в країні, в нотах, що виражають співчуття. Принцип взаємності є по суті персуазивним [10]. Дотримання цього принципу $\epsilon$ важливим чинником цивілізаційного прогресу, оскільки він сприяє встановленню тривалих відносин і обмінів, без яких неможливий розвиток суспільства. Правило взаємного обміну часто використовують у дипломатії, де досить важливим є обмін взаємними послугами, голосами, зобов'язаннями тощо. Це простежується у взаємодії різних гілок і рівнів влади, в процесі лобіювання, ухвалення законів, у міждержавних переговорах.

Висновки 3 даного дослідження i перспективи. Таким чином, дипломатичний дискурс є окремим типом дискурсу, основними ознаками якого $€$ інтердискурсивність, наявність масового адресата, використання кооперативних та конфронтативних стратегій, ритуалізованість, діалогічність, а також персуазивність. На мовному рівні персуазивний вплив у дипломатичній комунікації реалізують за допомогою різноманітних лексичних, граматичних, синтаксичних і стилістичних засобів. Перспективою дослідження може бути встановлення особливостей перекладу мовних засобів персуазивності в дипломатичному дискурсі.

\section{Список викристаних джерел:}

1. Аристотель. Риторика. Поэтика / Аристотель. - Москва : Лабиринт, 2000. -224 c.

2. Голоднов А. В. Лингвопрагматические особенности персуазивной коммуникации (На примере современной немецкоязычной рекламы) : дис. ... канд. филол. наук: 10.02.04 / А. В. Голоднов ; Рос. ГПУ им. А. И. Герцена. Санкт-Петербург, 2003 - 247 с. 
3. Кащишин Н. Є. Експресивність термінів англомовного дипломатичного дискурсу / Н. Є. Кащишин // Наукові записки Ніжин. держ. ун-ту ім. М. Гоголя. Сер.: Філологічні науки. - 2014. - Кн. 2. - С. 93-98.

4. Мицик В. В. Становлення концепції превентивної дипломатії / В. В. Мицик // Європейські перспективи : наук. журн. - Київ, 2003. - № 1. C. 3-21.

5. Пономаренко О. Інтердискурсивність як провідна риса дипломатичного дискурсу (на матеріалі виступів екс-Міністра закордонних справ Італії Дж. Терці ді Сант-Агата на IX Конференції Послів у Римі) / О. Пономаренко // Вісник Київ. нац. ун-ту імені Тараса Шевченка. Іноземна філологія. - 2014. - № 1. - С. 30-35.

6. Попов В. И. Современная дипломатия: теория и практика. Дипломатия - наука и искусство : курс лекций / В. И. Попов. - Москва, 2004. $576 \mathrm{c}$.

7. Судус Ю. В. Стратегія дискредитації в англомовному дипломатичному дискурсі / Ю. В. Судус // Мова і соціум: етнокультурний аспект : матеріали IV Міжнар. конф. мол. уч. Бердянськ, 19-20 верес. 2014 р. - Бердянськ : БДПУ, 2014. - C. 83-84.

8. Терентий Л. М. Дипломатический дискурс как особая форма политической коммуникации / Л. М. Терентий // Вопросы когнитивной лингвистики. - 2010. - № 1. - С. 47-56.

9. Чернявская В. Е. Дискурс власти и власть дискурса: проблемы речевого воздействия / В. Е. Чернявская. - Москва : Флинта : Наука, 2006. $136 \mathrm{c}$.

10. Cialdini R. B. Influence / R. B. Cialdini. - New York : William Morrow and Company, 1984. - 302 p.

11. Dijk T. A. Discourse and Manipulation / T. A. Dijk // Discource \& Society. - L. : SAGE Publications, 2006. - Vol. 17. - P. 359-383.

12. Perelman Ch. A New Rhetoric: A Treatise on Argumentation. - Notre Dame (Ind.) : Univ. of Notre Dame Press, 2000. - 566 p.

13. Sasson Sofer. The Courtiers of Civilization: A Study of Diplomacy. Albany: State University of New York Press, 2013. - 124 p.

14. UNO Security Council Resolution 1970

http://www.un.org/ga/search/view_doc.asp?symbol=S/RES/1970\%20\%282011\%29/. - Last access 01.02.2018. - Title from the screen.

\section{References:}

1. Aristotle. (2000). Rhetoric. Poetics. Moscow : Labyrint. 
2. Golodnov, A.V. (2003). Linguistic and Pragmatic features of Persuasive Communication (Based on Contemporary German-Language Advertising). D.Ed. Russian State Pedagogical University named after A. I. Gertcen.

3. Kashchyshyn, N.E. (2014). Expressiveness of English Diplomatic Discourse Terms. Naukovi Zapysky Nizhynskoho Derzhavnoho Universytetu im. Mykoly Hoholia. Ser. : Philolohichni Nauky [Scientific Notes of Mykola Hogol Nizhyn State University. Series: Philological Sciences], Book. 2, pp. 93-98.

4. Mytsyk, V.V. (2003). Formation of Preventive Diplomacy Concept. Yevropeiski perspektyvy: Naukovyi Zhurnal [Scientific Journal: European Perspectives], no. 1, pp. 3-21.

5. Ponomarenko, O. (2014). Interdiskursivity as a Leading Feature of Diplomatic Discourse (Based on Speeches of Ex-Minister of Italian Foreign Affairs J. Terci di Sant Agat at the IX Conference of Ambassadors in Rome). Visnyk Kyivskoho Natsionalnoho Universytetu imeni Tarasa Shevchenka. Inozemna Philolohiia [Bulletin of Taras Shevchenko National University. Foreign Philology], no. 1. pp. 30-35.

6. Popov, V.I. (2004). Modern Diplomacy: Theory and Practice. DiplomacyScience and Art: Collection of Lectures. Moscow.

7. Sudus, Yu.V. (2014). The Strategy of Discrediting in English Diplomatic Discourse. V: Language and Society: Ethno-Cultural Aspect: IV International Conference of Young Scientists Materials, Ukraine, Berdiansk, September 19-20, 2014. Berdiansk : Berdiansk State Pedagogical University, pp. 83-84.

8. Terentii, L.M. (2010). Diplomatic discourse as a Special Form of Political Communication. Voprosy Kognitivnoi Lingvistiki [Questions of Cognitive Linguistics], no. 1, pp.47-56.

9. Chernyavskaya, V.E. (2006). Discourse of Power and Discourse Power: Issues of Speech Influence. Moscow : Flint: Science.

10. Cialdini, R.B. (1984). Influence. - N.Y.: William Morrow and Company.

11. Dijk, T. A. (2006). Discourse and Manipulation. Discource \& Society, Vol. 17, pp. 359-383.

12. Perelman, Ch. (2000). A New Rhetoric: A Treatise on Argumentation. Notre Dame (Ind.): Univ. of Notre Dame Press.

13. Sasson, S. (2013). The Courtiers of Civilization: A Study of Diplomacy. Albany: State University of New York Press.

14. The UN. (2011). UNO Security Council Resolution 1970. [online] Available at http://www.un.org/ga/search/view_doc.asp?symbol=S/RES/1970\%20\%282011\%29. [Accessed 1 February 2018]. Title from the screen.

(C) Скрябіна В. Б., 2018 